\title{
Vision Of An Attractive Social Studies Class: An Exploratory Study At Secondary Level
}

\author{
D.N.Singh, \\ Ph.D. Scholar,Jamia Millia Islamia, New Delhi
}

\begin{abstract}
Education is the development of all those capacities in the individual which will enable him to control his environment and fulfill his possibilities"

John Dewey
\end{abstract}

Present paper is an attempt to bring attention of all the stakeholders of education especially secondary education towards the lack of interest in Social sciences amongst students at secondary level. In today's twenty first century our life is full of complexities and such complex and challenging environment can be controlled by a responsible, value oriented and well aware citizen of a democracy. These qualities bearing citizen will not only fulfil his personal and professional possibilities but also the real possibilities of democratic spirit. It is important to reinstate the significance of the social studies by not only highlighting its increasing relevance for a job in the rapidly expanding service sector, but by pointing to its indispensability in laying the foundations for an analytical and creative mindset beneficial for the society as well as for the nation. The social studies carry a popular base for human values like freedom, trust, mutual respect and respect for diversity in the children. Social studies serve this purpose of bringing such qualities amongst the pupils at school level. It provides energy to pupils to think independently and deal with the social forces that threaten these values. And, this can happen if they may take interest in social studies at their adolescent stage to become a full-fledged member of the society in future. Through effective social studies education pupils would be able to think about individual good and collective well. So, it is necessary to revitalize social studies teaching in a better interactive environment of the classroom by the teacher. It has often been noticed that there is an increasing gap between the promises made in the prescribed curriculum and what is happening at the level of child's perception. So an attractive environment of social studies class will bring attention, interest, motivation and positive attitude amongst the pupils to serve the mankind in latter stage. They will feel enthusiastic in the live environment of the class and learn optimum. Thus the pupils will be equipped and prepared to meet the challenges of a successful social life. Hence the urgent demand for a better social studies education must be created and this could be done through the vision of an attractive social studies class. It is the classroom where a teacher has to play a big and challenging role of an efficient classroom manager to create conducive environment and make the subject more interesting through all possible ways. A teacher should choose and adopt the best possible strategy to transact the content reachable to every students of the class. Selection of any strategy must be made according to the natural requirement of the topic and level of the learners so that it will not only develop their cognitive aspect but also affective domain. It has been found that least effective strategies are practiced more and more in maximum schools by the teachers. So, there is a great need to make use of most effective learning materials to make social studies teaching and learning more attractive, interesting and live. To achieve the aims and objectives of teaching social studies at secondary level the investigator tried to know the perception of students, subject-teachers and Teacher-Educators so that the vision of an attractive social studies class can be materialized in reality.

\section{Introduction}

It is generally recognized that every one must be supplied some valuable insight into the structure of society in order to be prepared to meet the exigencies of life. Hence an urgent demand for instruction in social studies was created. The culture of social studies was first preached and promoted in the U.S.A. in 1916. In Britain, the establishment of Association of Education in World Citizenship in 1935, acted as pressure group for the inclusion of social studies in the school curriculum. The social studies came to be recognized as a subject of school curriculum in India with the advent of Basic Education in 1937. But it was included as a subject at secondary level when Secondary Education Commission highlighted its value and importance in 1952. Since then social studies has been forwarding ahead. The social studies carry a normative responsibility to create and widen the popular base for peace- oriented human values such as freedom, justice and respect for diversity. So it is very much essential to give due weightage to social science subjects at this school level and there must be an attractive classroom means a very much learning friendly classroom having conducive environment. It is well known fact that appropriate learning environment or congenial learning environment is an essential prerequisite 
for effective learning. If the learning environment in the classroom is appropriate, no doubt the students will take interest in the subject and their achievement will improve. But does the existing learning environment in the social studies classroom is congenial enough to deliver the content effectively. It can be said no because the observations of existing scenario, direct me to think again and again about the commonly practiced teaching methods in most of the social science classrooms. After assessing the various social science classes in government and private institutions, we may find out the 'least' effective materials are commonly practiced in the classes of social sciences by the teachers.

\section{Need For The Study}

The intellectual development of the learner varies with age. At the secondary level, the pupils are passing through a transitional period of adolescent. It is widely accepted that at such a stage of growth social studies should constitute the core curriculum. E.W.Tiegs has also observed the similar views "the social studies are the heart of the curriculum. They must permeate and give significance to the whole school programme." The curriculum should be like a smooth continuum moving the pupils to higher levels of development. A number of surveys have shown that social studies ranks in the middle in the list of pupil's preference of subjects at school level. Even the investigator encountered so many things in the social studies class during practice teaching, which propelled him to do this study. All these have made the 'Teaching of social studies' as a challenging task at secondary level. But when we see the teaching methodologies adopted by social studies teachers at the secondary level - it is still traditional way of textbook method dominating. In many instances textbooks are the only material available in schools. It does not contribute towards building their behavior pattern desirably. The over emphasis of textbook kills the interest in the subject and there by the subject becomes unpopular at the secondary stage of school education. Verbal symbols and pictures in the textbook have created much effectiveness on student's learning but also made the new text books more complicated. This need to be assessed in the context of perception of three partner's i.e. Teacher Educators, Teachers and students. Perhaps in the existing situation students, teachers and teacher-educators may have different perceptions about classroom environment and classroom instructions. Just to know this similarity or difference in their perceptions, the investigator tried to conduct this study. The investigator also wanted to know the gap between the ideal concept of congenial environment and the existing perceptions of students, subject-teachers and teacher-educators.

\section{Objectives Of The Study}

1) To study the perception of the students, the subject teachers and the teacher-educators towards existing classroom interaction between the teacher and students, existing classroom environment and existing curriculum.

2) To study the perception of students, teachers and teacher-educators towards the prospective use of teaching aids and I.C.T. in social studies teaching in the class, prospective classroom instructions and environment.

3) To study the perception of students, teachers and teacher-educators towards the use of Integrated approach of teaching social studies in the classroom.

4) To study about the perception of students, teachers and teacher-educators towards the vision of an attractive social studies class.

\section{Delimitation Of The Study}

Following are the delimitations of the study:

1. The study is confined to N. C.T. of Delhi.

2. Sex difference is not taken into consideration.

3. Old term "Social Studies" used in lieu of new term "Social Sciences"

4. Only class $10^{\text {th }}$ students taken as Secondary Level Students for the study

\section{Methodology}

Survey technique under descriptive method of research was used to conduct the present study. Data analyzed on the basis of perception scale mentioned earlier. Data regarding to the perception of three groups of subject was analyzed qualitatively and qualitatively.

\section{Population}

The population was comprised of students at secondary level $\left(10^{\text {th }}\right)$, the social studies teacher at the same level and the Teacher-Educators concerned with teaching method of social sciences for secondary teacher education. 
Sample

There were three groups of samples selected for the present study. They were -100 secondary level students, 30 subject-teachers at the same level \& 30 teacher-educators concerned with teaching method of social sciences for secondary teacher education. The samples of secondary students were randomly selected from three different schools of South Delhi. The representative samples of subject-teachers were selected from seven different secondary schools also from South Delhi. Teacher-educators related to teaching method of social sciences were selected purposely from Jamia Millia Islamia, University of Delhi and affiliated institutes of G.G.S.I.P.U., New Delhi.

Tool

In order to achieve the objectives of the study, the investigator used the self-prepared tool. For the present study the tool employed was the Perception Scale. To know the perception of the students, subjectteachers and the teacher-educators towards the "Vision of an attractive social studies class: an exploratory study at secondary level"- three Perception Scales were devised separately for three groups of subjects after the consultation with experts in the field of Teacher Education. It was closed ended form Perception Scale consisting 30 items in each representing six major dimensions. Special emphasis was given to those wordings and terminology, which were important to fulfill the objectives. All the three Perception Scales were planned according to the levels of the samples of the three separate groups of subjects. The questions were based on the classroom instructions, classroom environment, student's interest, activity based teaching, use of information communication technologies in the classroom, existing teaching strategies adopted by the subject teachers, existing curriculum and integrated approach of teaching social studies. The respondents had to tick the one response out of three options given as always, sometimes and never. On the basis of the scoring key- 0-mark was allotted for 'Never', 1-mark for 'sometimes' and 2-marks for 'always'. Data collected separately for the three groups of subjects.

\section{Data Collection}

The survey was conducted in two phases. Firstly, the investigator surveyed the schools to get the responses from the students and the subject-teachers. And, secondly got the responses from teacher-educators concerned with methodology of teaching Social sciences. The above mentioned scales were administered on the three subjects by following all possible formalities. The scoring was done with the help of scoring key after collecting the data. The Perception Scale for students, teachers and teacher-educators compiled systematically.

\section{Results}

The mean performance of three groups of subjects regarding six dimensions of perception scales, are displayed below with the help of tables \& bar diagrams. Perception of the subjects can be analyzed separately under the following headings:

\section{A) PERCEPTION OF STUDENTS:}

Table-1: Mean Performance of sample of students on different dimensions of Perception Scale $(\mathbf{N}=\mathbf{1 0 0})$

\begin{tabular}{|l|l|c|}
\hline S.No. & & \multicolumn{1}{|c|}{ Dimensions } \\
\hline 1. & Existing C.R. interaction between teacher \& student. & Mean \\
\hline 2. & Existing C.R. environment & 0.894 \\
\hline 3. & Existing curriculum & 0.717 \\
\hline 4. & Prospective use of T.A. \& I.C.T. in the C.R. & 1.360 \\
\hline 5. & Prospective C.R. instructions \& environment & 1.790 \\
\hline 6. & Integrated approach of teaching S.St. & 1.866 \\
\hline
\end{tabular}

A-1.Towards existing classroom interaction between the teacher and students in the social studies class:

i) Students' perception clearly revealed that existing classroom interaction between the teacher and students was not satisfactory.

ii) The teachers rarely encourage students to ask questions while teaching in the class.

iii) The teachers never give immediate feedback to the students after checking their homework.

iv) The teacher teaches the students in a monotonous way in the class.

v) Students rarely get a chance to interact with the teacher to express their independent views.

\section{A-2.Towards existing classroom environment during social studies class:}

i) Students are not satisfied with the existing classroom environment.

ii) Teachers do not use teaching aids regularly in social studies class. 
iii) Students never get a chance for group discussion, debate, and dialogue - related to subject matter in the class.

iv) Teachers rarely give relevant and local examples in the class.

\section{A-3.Towards existing curriculum:}

i) Students found the existing curriculum is vast and lengthy.

ii) Students also found some unimportant topics in the curriculum.

A-4.Towards prospective use of teaching aids and information communication technologies in social studies teaching:

i) Students are very curious to see the prospective use of Teaching Aids and I.C.T. in their social studies class.

ii) According to them teachings aids and I.C.T. would have very much prospect in the social studies teaching as they activate the mental process of students.

iii) Students believed that T.A. and I.C.T. would make their concept clear.

iv) T.A. \& I.C.T. based learning would remain much longer in their memory.

v) T.A. \& I.C.T. would make the class more attractive and interesting as these aids were best motivators.

vi) T.A. and I.C.T. would provide a substitute of real experiences to the students in the classroom.

\section{A-5.Towards the vision of classroom instructions and environment:}

i) Students learn more by doing activities and they want to see their teachers to arrange some activities related to curriculum.

ii) They may get behavioral knowledge by doing an activity.

iii) Well presented lesson by the teacher would create good classroom environment.

iv) Students wanted some democratic environment in the class.

v) Inviting students to ask questions and debate would prove effective classroom instruction.

\section{A-6.Towards integrated approach of teaching social studies}

i) Textbook teaching method by the teacher created a monotonous atmosphere in the class, which was killing the interest of the students in the subject and they get bored.

ii) Textbook method of teaching doesn't create interest and also found not suitable for complicated topics.

iii) Groups' formation for discussion, projects, assignments etc would maintain the interest level of the students in the subject. Some activities based teaching would be placed in the routine to make the students fresh.

iv) Integrated teaching approach was found most suitable to teach social studies.

\section{B) PERCEPTION OF SUBJECT-TEACHERS:}

Table- 2: Mean Performance of Samples of teachers on different dimensions of Perception Scale $(\mathrm{N}=\mathbf{3 0})$

\begin{tabular}{|l|l|c|}
\hline S.No. & \multicolumn{1}{|c|}{ Dimensions } & Mean \\
\hline 1. & Existing C.R. interaction between teacher \& student. & 1.372 \\
\hline 2. & Existing C.R. environment & 1.230 \\
\hline 3. & Existing curriculum & 1.070 \\
\hline 4. & Prospective use of T.A. \& I.C.T. in the C.R. & 1.772 \\
\hline 5. & Prospective C.R. instructions \& environment & 1.780 \\
\hline 6. & Integrated approach of teaching S.St. & 1.776 \\
\hline
\end{tabular}

\section{B-1.Towards existing C.R. interaction between the teacher and students:}

i) Teachers themselves are not satisfied with the existing classroom interaction between the teacher and students.

ii) Teachers don't adopt different teaching strategies to teach social studies.

iii) Teachers don't ask questions oftenly while teaching in the class.

iv) Teachers don't provide any feedback after checking the homework of the students.

v) Teachers never do individual interaction in the class.

\section{B-2.Towards existing C.R. environment:}

i) Teachers themselves keep a perception that the condition of classroom environment was not up to the desired level.

ii) They accept that they do not use teaching aids regularly in social studies teaching.

iii) Teachers rarely arrange any actively based teaching-learning strategy. 
iv) Students' readiness isn't satisfactory during the social studies class-was the perception of teachers.

B-3.Perception of Teachers towards existing curriculum:

i) Teachers also found the social studies curriculum is vast and lengthy.

ii) Due to vast and lengthy syllabus they don't get enough time to arrange any activity or debate etc in the class.

iii) Teachers also found some unimportant contents in the syllabus and left them over to the students.

B-4.Perception of Teachers towards prospective use of T.A. and I.C.T. in

S. St. class:

i) T.A. and I.C.T. should be used in the teaching of subject like social studies to motivate the students.

ii) T.A. and I.C.T. would create interest and attention for the subject among the students.

iii) T.A. and I.C.T. would activate the mental process of the students and also change the monotonous atmosphere of the classroom.

iv) These aids are fundamental to verbal instructions.

v) There must be a separate Social Studies Laboratory equipped with all kinds of aids and modern technologies to teach social studies.

B-5.Perception of teachers towards classroom instructions and environment:

i) Mastery over the subject and deep understanding of teaching-learning process will create good classroom environment in the social studies teaching.

ii) Personality of individual teacher is a significant factor to effective classroom instructions and environment.

iii) Teachers say that debate, discussion, dialogue would bring students closer to the teacher which ultimately helps to create effective classroom environment.

iv) Enthusiasm of the teacher is helpful in effective classroom instructions.

B-6.Perception of teachers towards integrated approach of teaching social studies:

i) Similar teaching strategy isn't always suitable for all the contents of social studies curriculum.

ii) Integrated teaching approach maintains the interest level of the students \& brings change in the monotonous atmosphere of the class.

C) PERCEPTION OF TEACHER-EDUCATORS:

Table-3: Mean performance of sample of teacher-educators on different dimensions of Perception Scale

\begin{tabular}{|l|l|c|}
\hline S.No. & \multicolumn{1}{|c|}{ Dimensions } & Mean \\
\hline 1. & Existing classroom interaction & 1.070 \\
\hline 2. & Existing classroom environment & 1.266 \\
\hline 3. & Existing curriculum & 1.330 \\
\hline 4. & Prospective use of T.A. \& I.C.T. & 1.770 \\
\hline 5. & Prospective classroom instructions and environment. & 1.750 \\
\hline 6. & Integrated approach of teaching social studies & 1.780 \\
\hline
\end{tabular}

C-1.Towards existing classroom interaction between teacher and students:

i) Teacher-educators aren't fully satisfied with the existing status of social studies and its' classroom interaction.

ii) Teacher-educators aren't happy with the performance of the teachers.

iii) They believe that teachers don't put their total efficiency to teach in the class.

C-2.Towards existing classroom environment:

i) They have perception that teachers don't bother too much to plan the lesson before teaching in the class.

ii) They have an opinion that teachers don't use their total efficiency to create a conducive environment in the class.

C-3.Perception of Teacher-Educators towards existing curriculum:

i) They realized that the curriculum is really vast and lengthy but also suggested that the individual teacher might be able to overcome of this problem by using their total efficiency.

ii) They gave an opinion to empower the teacher training programme based on real problematic situation of the classroom.

C-4.Perception of Teacher-educators towards the Prospective use of teaching-aids and I.C.T. in the class:

i) T.A. and I.C.T. should be used usually in the class to teach social studies.

ii) T.A. and I.C.T. would make the lesson more interesting as these aids give various experiences.

iii) Learning through these modern technologies would remain much longer in the memory of students.

iv) T.A. and I.C.T. are better substitute of learning for the students as they bring scientific outlook.

v) Teachers should have expertise of using T.A.\& I.C.T. at exact point of teaching. 


\section{C-5.Perception of teacher-educators towards prospective classroom environment and instructions:}

i) Enthusiasm and efficiency of a teacher play a big role to deliver effective classroom instructions and also help to create effective classroom environment.

ii) Debate, discussions, clearly structured and pre-planned lessons are the factors to create a prospective classroom instructions and environment.

iii) Appropriate and intelligent questioning pattern of asking questions by the teacher would be a miracle to establish an effective classroom environment and instructions.

C-6.Perception of teacher-educators towards integrated approach of teaching social studies:

i) Integrated approach of teaching is the most suitable to teach multifaceted social studies curriculum.

ii) Group projects, group discussion, group assignment should be added to integrated approach to teach social studies.

iii) To change the monotonous atmosphere and to create interest - a teacher should have to choose appropriate teaching strategy to teach the individual topic of the subject.

\section{Suggestions}

1. Related to Existing Classroom Interaction between the teacher and students:

i) The textbook undoubtedly was an important instruction material and could not be ignored in the teaching-learning process of social studies in the class but its overemphasis would kill the interest among the pupils. So the teacher would take help of various kinds of teaching aids to explain the lesson and use them on required occasions on exact point.

ii) Teachers would interact with students in a friendly atmosphere and would encourage students to ask questions and clear their doubts. It had been found that generally classroom instruction was dominated and directed by the teachers.

iii) Students would be given the task of group projects, group assignments by the teacher so that they could learn the importance of social association.

iv) Teachers should have to be quite conscious of providing feedback to every individual student after checking their homework because corrective feedback would raise the confidence of the students and push them to do better in the subject.

v) Teachers should have to be well aware that uniform way of teaching kills the interest among the pupils. They would adopt integrated approach to maintain the interest in students for the subject. They would choose the appropriate teaching strategies to suit the topic of the syllabus and bring maximum learning outcomes.

\section{Related to the Existing Classroom environment:}

i) While dealing with the students the teacher would be careful of making a good rapport in the minds of students, so that they could not hesitate to ask questions from the teacher. To create a democratic environment, the teacher would talk friendly with pupils.

ii) To cultivate a social value among the pupils, group tasks would be given. Grouping might bring some social qualities and motivation among the pupils automatically. To improve the classroom environment, the teacher would take note that he/she was the incharge of the class and would try to win the pupils. The teachers should have to set up a democratic environment in the class.

iii) Teachers should have to provide some chances for dialogue to the students, which would break the hesitation of the students. Content related dialogue would create a progressive environment in the class and the effectiveness of teaching would give impact on the whole class.

iv) To give local and relevant examples by the teacher in the class would create a good and interesting environment before the student. All the students would show alertness while local examples would be discussed in the context of the topic being taught in the class.

v) It was well known that educational excursions would bring all the pupils closer to the each other and would also bring some attention towards the goal of the excursions. Report making after the excursion should had to be made compulsory to all the students. This way, they would think constructively and also enrich their knowledge.

\section{Related to the Existing Curriculum:}

i) To see the lengthy and vast syllabus of social studies at secondary level, majority of the teachers just wanted to finish the course on the time. They did not get enough time to revise the syllabus and would not find out time to arrange content based activities in the class. This was not a healthy practice because students rarely got a chance of getting proper and in depth knowledge of the subject. Off course the syllabus must be completed on time but thorough knowledge of the content was also essential.

ii) To overcome of this problem teaches would use their total efficiency to transact the knowledge to the students. All the teachers should have to be extra cautious to prepare lesson in advance. What had to be 
taught, when to use teaching aids, what amount of interaction ahs to be made with the students. All these things should have to be planned in advance.

iii) The teacher-educators would take care of the training provided to the teachers during pre-service and inservice training programmes.

4. Related to the Prospective use of T.A. and I.C.T.:

i) Teaching aids and I.C.T. would be used properly in the class to make the lesson more attractive and interesting. Teaching aids and I.C.T. would activate the mental process of the students. These aids would clear the conception of ideas, information, facts and principles. These aids would bring a change in the monotonous atmosphere that generally prevails in the classroom. It would be also helpful to teach bigger class.

ii) There were many aspects in the history and geography portion where I.C.T. would prove a miracle to explain the topic. The teacher should had to posses the required knowledge and skills to handle such devices and they also would be aware when and how much to use such technologies in at what point of time.

iii) It is obvious that audio - visual experiences would provide a substitute of real experiences to the adolescent pupils of secondary level. They would learn quickly with the help of visual explanations and such learning would remain much longer in their memory.

iv) Appropriate and intelligent use of such aids would make the teaching more effective. Subject like social studies needed very much help from these technologies, where students consider this subject as second choice.

5. Related to the prospective classroom instructions and environment:

i) A prospective desired classroom instructions and environment would prove a milestone in teaching of social studies. Teachers would try to put some activities based learning to the students because the students get bored of their routine textbook learning. Learning through activities would keep their mind fresh and ready to take challenges. It would also help students to make and maintain a better relationship with others.

ii) All the teacher should had to be the master of the subject as well as a very sound knowledge of educational psychology and other teaching-learning processes. They would be fully conversant with the methodology and techniques of teaching. A scholarly teacher would be always loved and respected by the students.

iii) To create a conducive and progressive classroom environment the teacher should arrange prized debate, group discussion in the class according to the availability of time and resources. They should create a democratic atmosphere so that the pupils would express their independent views and enrich their knowledge by exchanging the thoughts. A better classroom relationship with the students would empower the teacher to maintain a warm, supportive environment even from the pupils to contribute constructively in the class. Teaches who were perceived as being understanding, helpful and friendly and show leadership without being too strict had been found to enhance pupils' achievement.

iv) The teacher of social studies would work as facilitators in the classroom so he would focus his teaching strategies towards child centered approach. The classroom environment would be a reflection of the teacher's teaching strategies. The student centered model would promote high level thinking skills and would be sensitive to the abilities and idiosyncrasies of each student.

6. Related to Integrated approach of teaching social studies:

i) Only textbook approach of teaching social studies would bring fatigue and boredom to the students, which killed the interest of the students. It was also very much significant that the social studies is comprised of history, political science, geography, economics and disaster management and all these portions of the subject required different kinds of teaching strategies.

ii) Integrated approach of teaching should have to be adopted by the teacher because it was the most suitable to teach the diversified contents of social studies. It would be comprised of group projects, group assignments, group study, and use of different strategies to make the lesson easily understandable to the pupils.

\section{BOOKS:}

\section{References}

[1]. Bhattacharya, S. and Dorji, D.R. (1966). Teaching Social Studies in Indian Schools, Baroda: Acharya Book Depot.

[2]. Best J.W. and Khan J.V. (1992), Research in Education, NewDelhi: Prentice Hall of India.

[3]. Binning A.C. and Binning D.H. (1952): Teaching the Social Studies in Secondary Schools, New York: McGraw-Hill Book Co.

[4]. Dhand, Harry (2009).A Handbook for Teachers: Research in Teaching of Social Studies, Delhi : Ashish Publishing House.

[5]. Fenton, Edwin (2006). Teaching the New Social Studies in Secondary Schools, Carnegie Int. of Technology, Newyork: Rinehart \&Winston Inc.

[6]. Hemming J.: 1956 The Teaching of Social Studies in Secondary Schools, London: Longman

[7]. Johnson, E.S. (1956).Theory and Practice of the Social Studies, New York: MacMillan Co. 
[8]. Mclendon, Jonathan C. (1965) Social Studies in Secondary Education, New York: MacMillan Co.

\section{Journals and Periodicals:}

[9]. Dissertation Abstracts International (A) - The Humanities and Social Sciences (1986) University Microfilms Int., Michigan, USA.

[10]. Educational Researcher, (2005-06). Vol. 35, NO.-7, American Educational Research Association.

[11]. Journal of Teacher Education, (2007) Vol. 58, No.2,

\section{Polices, Reports and Documents}

[12]. Report of Secondary Education Commission, (1953).Govt. of India, Ministry of Education, New Delhi

[13]. National Policy of Education-1986, Govt. of India, Ministry of HRD,NewDelhi

[14]. National Curriculum Framework-2005, NCERT,NewDelhi

[15]. Buch M.B. (Ed.). Fourth Survey of Research in Education (1983-88) Vol. I \& II, NCERT.

[16]. Internet Sources 